necessary both to search for stable configurations, with associated geometrical complications, and to try to understand the nature of the unstable Hlow patterns, a problem similar to fluid turbulence. Then, it must be remembered that magneto-hydrodynamies gives only a rough picture of an ionized gas and there is a range of problems associated with the kinetic theory of a fluid composed of particles interacting through magnetic fields. Finally, there are unanswered questions at the basis of the entire theoretical structure. What constitutes a collision between particles interacting by a long-range force such as an electric field? Under what conditions can
Boltzmann's equation describe a system composed of such particles? Some of these problems present conceptual difficulties and most of them tax mathematical ingenuity. Any that are solved may contribute to the production of thermonuclear power, and all will contribute to our understanding of important processes in Nature.

${ }^{2}$ Arnold, W. R., Phillips, J. A., Sawyer, G. A., Stovall, E. J., and Tuck, J. L., Phys. Rev., 93, 483 (1956).

Gamow, G., and Teller, E., Phys. Rev., 53, 608 (1938). Thompson, 1 (1957).

Heitler, W., "The Quantum Theory of Radiation", 172 (2nd edit. Press, 1944).

- Pease, R. S., Proc. Phys. Soc. B, 70, 11 (1957).

\title{
THE GASTROPOD SHELL
}

$\mathrm{O}$ $\mathrm{N}$ the evening of March 13, following last year's precedent, a well-attended open discussion meeting, organized by the Malacological Society of London, was held in the rooms of the Linnean Society. Prof. A. Graham, of the University of Reading, was in the ehair, and the topic was "The Gastropod Shell".

Dr. L. R. Cox, of the Department of Palæontology, British Museum (Natural History), referred first to the general questions of the origin of the Gastropoda and of asymmetrical coiling. The class owes its distinctive features to the episode in early ontogeny known as torsion; and the theory now most favoured, that of Garstang, is that torsion originated as a genetic mutation affecting the larval stage of some primitive mollusc. The view of Wenz and Knight was that this ancestral form belonged to the supposedly long extinct, cap-shaped Monoplacophora, which had been thought to have had an internal organization similar in many respects to that of the chitons; the rearrangement of respiratory, excretory and other internal organs consequent upon torsion could have favoured the development of an extended visceral mass which soon proved to be best accommodated in a coiled shell. The important discovery has, however, recently been made of a surviving monoplacophoran (Lemche, Nature, 179, 413; 1957), and its metameric organization suggests that this group, if ancestral to the gastropods, was more distantly so than has been supposed. Significant also is the observation that this modern monoplacophoran has a coiled protoconch, suggesting that a tendency to spirality existed before torsion.

The bellerophonts, in which the shell has complete bilateral symmetry, are the earliest true torqued gastropods known to the palæontologist. In all modern coiled gastropods the shell is asymmetrical, and in most of them a dextral shell is associated with dextral soft parts (genitalia on the right). An asymmetrical gastropod could develop from one with a symmetrical (isostrophic) shell and dextral or potentially dextral soft parts in two ways-when the animal's head faces to the front the spire could protrude either to the right (giving the typical orthostrophic dextral shell) or to the left, giving an apparently sinistral shell best referred to as hyperstrophic. The hyperstrophic condition, now so rare in the adult shell, was explored in Lower Palæozoic times by a whole superfamily of gastropods, the Macluritacea, but evidently proved less successful than orthostrophic coiling. The heterostrophic protoconch of many living opisthobranchs, constituting the larval shell, is, in fact, hyperstrophic. The change from hyperstrophic to orthostrophic coiling when the gastropod begins life as a creeper on the sea-floor appears to demand some explanation.

The palæontologist, accustomed to subject every structure of the shell to careful scrutiny to assess its taxonomic importance, is constantly led to ask what is its functional significance. Reliable answers to many questions have not yet been found and must be based on careful observations on living gastropods. Certain features of the outer lip of the aperture are a case in point. It has always been assumed that the slit found in the pleurotomarians and bellerophonts is for the exhalant current, and this has been confirmed by observations on living zygobranchs, such as Haliotis. The sinus at or near the adapical end of the outer lip in the Turridae and Conidae is commonly assumed to have an exhalant function. In the Cerithiidse and other families a channel-like extension of the aperture is referred to as a "posterior canal' and regarded as an exhalant channel ; but the extinct cerithiid genus Vicarya had also a deop labral slit like that of the pleurotomarians. Is the long canal-like adapical extension of the aperture in Tibia and Strombus an exhalant channel? Some Strombus have both this channel and a sinus in the outer lip near the suture recalling that of Conus. The long, narrow, canal-like adapical extension of the aperture in Rimella is often interpreted as exhalant, but is perhaps merely a labral digitation of unknown function. In Aporrhais, as shown by Yonge, the exhalant current passes through a sinus below a comparable digitation adhering to the spire. Finally, what is the significance of the great differences in the curves of the outer lip in various Turritellidas?

Dr. A. Comfort (University College, London) discussed the pigmentation of shells, illustrating his remarks with colour slides and chromatograms. The shell pattern is produced by the activity of pigmentdepositing points or areas in the mantle edge-the intermittency or apparent movement of these points is projected in the pattern, and can be followed stage by stage. The pigment-producing cells appear to show periodicities like those of feather melanoblasts, and there is in many cases a tendency for pigment production to spread outward along the mantle edge from a focus, dying out in its original site, and producing the typical $V$-shap elements found in many marine shells. The pigments present in the protein and calcareous layers of shells 
fall into two sharp groups; in the archæogastropods they are predominantly acid-soluble, pyrrolic substances, whereas in all pulmonates and most higher prosobranchs they are non-extractable protein-bound materials. Uroporphyrin occurs in large amounts in archæogastropod shells, and also in a few other groups (tectibranch opisthobranchs, certain Cypraeidae, etc.). In others (Turbo, Haliotis), it is apparently replaced by linear tetrapyrroles often of an unusual kind and in mixtures which paper chromatography has shown to be highly complex. iso-Uroporphyrin also occurs in some Trochidae. Coproporphyrin has not been found.

The source and function of these substances are not known, but are possibly dietary, the shell providing a means of disposing of porphyrins or their degradation products. The colour of pulmonates (Cepaea) has, however, been shown experimentally to influence selection by predators, and the complexity of shell pigmentation in other forms makes it difficult to believe that it has no similar adaptive function.

Dr. D. R. Crofts (Queen Elizabeth College, London) dealt with the subject of "Muscles and Torsion in Gastropods". Garstang, in 1929, made the suggestion that torsion might have originated ancestrally during pelagic larval development in response to larval needs, bringing the mantle cavity with its contents into a dorsal position behind the head and so allowing for the withdrawal of the head and foot within the shell for protection. This position of the mantle cavity was by no means an advantage to the adult, allowing no free elimination of the waste products of respiration and excretion. Garstang emphasized that further changes, therefore, became necessary in the creeping adult because of torsion. Garstang's hypothesis was that a genetic mutation, having its phenotypic expression effective in the veliger stage, could have involved a pair of asymmetrical larval retractor muscles, namely, a right-hand head retractor with a posterior shell attachment and a left-side foot retractor with a more forward shell attachment, working more or less at right angles to one another. Ancestrally these two muscles might have brought about the whole $180^{\circ}$-torsion which Boutan (1898) thought took place in a few minutes.

From recent work on muscle development in primitive gastropods it is obvious that only one of the two muscles postulated by Garstang exists at the time larval torsion begins. This is the asymmetrical retractor developed from the mesoderm band of the pretorsional right side, having a posterior shell attachment on that side : the anterior attachments on the right retract the mantle and head, while those on the left curve dorsally over the gut and retract the left side of the head and foot. The retraction of this single asymmetrical muscle is responsible for the first part of the rotation and thus this muscle appears to be the primary ontogenetic cause of torsion. It might be the right member of an ancestral pair of muscles; the other member might be the post-torsional muscle of the right side (the adult columellar muscle), which is delayed in development until the second phase of torsion, during which the shell fixation of the original larval retractor migrates towards the final left side. At the completion of torsion the two muscles are equal in size. Their further modification does not occur until post-larval development. The two laterally placed equal muscles closely correspond with those of the adult Scissurella and might represent the two symmetrical retractor muscles of ancestral gastropods, the scars of which were discovered in the Palæozoic bellerophonts by Knight (1947). Contrary to general supposition, the early larval retractor does not become the columellar muscle. Lemche's study, at the Copenhagen Museum, of the organization of the muscle cells in the living monoplacophoran, which has not undergone torsion, is awaited with great interest.

In the ensuing discussion, to which a number of those present contributed, Dr. John Morton remarked that the long adapical canal of Rimella corresponds exactly in position to what would be needed for an efferent canal were the mollusc to burrow, as appears likely, like A porrhais and Struthiolaria. In general, the expanded outer lip in the Strombacea could be an adaptation, perhaps as a canopy against the fall of sediment; a small sinus low on the lip is to let out the right eye stalk, the left one coming out from the anterior canal. Dr. Comfort's picture of the distribution of porphyrin pigments in shells, chiefly in archæogastropods, primitive tectibranchs and primitive mesogastropods, previously difficult to explain, makes very good sense if fitted in with a postulated radial derivation of pulmonates, opisthobranchs, and higher mesogastropods from archæogastropods. L. R. Cox

\section{AEROBIOLOGY}

\begin{abstract}
$\mathrm{A}$ EROBIOLOGY may be defined as the study of the aerial transport of plants and animals or viable parts thereof, including flying animals (such as insects) in so far as passive movement is a major factor in their dispersal. A three-hour symposium on the subject was held by the Linnean Society of London on February 21, the president, Dr. H. Hamshaw Thomas, being in the chair.

The first speaker, Dr. J. M. Hirst (Rothamsted Experimental Station, Harpenden), said that, although spore dispersal is essential for the fertilization of many plants and for the wide distribution of saprophytic moulds, these aspects had received less attention than had the harmful effects of spores to man : direct effects in the form of allergic reactions or indirect in the form of plant diseases. For the study of both these kinds of effects it is necessary to
\end{abstract}

catch spores. Critical examination by Prof. P. H. Gregory of the various kinds of spore trap in use up to 1950 showed that freely exposed traps could never provide unbiased estimates of all constituents of the air spora at the frequent intervals necessary to show that their numbers were affected by changing weather. A new trap based on May's cascade impactor was therefore devised. This, the automatic volumetric spore trap, catches plant spores of all sizes with a high efficiency, and in particular it is much more efficient as a collector of small spores than is a freely exposed horizontal surface; though per contra the agar-coated Petri plate allows identification of colonies of fungi, the spores of which cannot be recognized microscopically. The daily trace obtained by the automatic volumetric spore trap is often clearly banded, and counts made of the 